\title{
DETERMINAN PEMILIHAN KARIR AKUNTAN
}

\author{
Endah Nurhawaeny ${ }^{1}$, Muzayyanah ${ }^{2}$, Surono $^{3}$, Itat Tatmimah ${ }^{4}$, M. Taufik Aziz \\ ${ }^{1,2,3,4.5}$ Program Studi Akuntansi Fakultas Ekonomi Univeritas Muhammadiyah Cirebon \\ e-mail : ${ }^{1}$ endah.nk@umc.ac.id; ${ }^{2}$ muzayyanah@umc.ac.id; ${ }^{3}$ surono.nrmn@gmail.com; \\ ${ }^{4}$ itat.tatmimah@umc.ac.id; ${ }^{5}$ taufikazis80@gmail.com
}

\begin{abstract}
The goal of this research is to find out what factors influence accounting students' decision to pursue a career as an accountant (accountants public, corporate, teaching, government). Variables the of consideration of the job market, work environment, financial rewards/salaries, and professional training are used to measure the factors that influence career choice. The respondents for this study were 72 accounting students from Muhammadiyah University of Cirebon's regular class who were in their 5th and 7th semesters. Multiple regression analysis with SPSS version 22 was used as the analytical method in this study. The findings revealed that labor market considerations, financial/salary rewards, and professional training had no significant impact on accounting students' decision to become accountants, whereas the work environment had a significant impact. accounting in order to pursue a career as an accountant.
\end{abstract}

Keywords: Career choice; job market considerations; work environment; monetary rewards; professional training

ABSTRAK

Tujuan dari penelitian ini adalah untuk mengetahui faktor-faktor apa yang mempengaruhi keputusan mahasiswa akuntansi untuk mengejar karir sebagai akuntan publik, perusahaan, pengajaran, pemerintah. Variabel pertimbangan pasar kerja, lingkungan kerja, imbalan keuangan / gaji, dan pelatihan profesional digunakan untuk mengukur faktor-faktor yang mempengaruhi pilihan karir. Responden untuk penelitian ini adalah 72 mahasiswa akuntansi dari universitas Muhammadiyah Cirebon kelas reguler yang berada di semester 5 dan 7 . Analisis regresi berganda dengan SPSS versi 22 digunakan sebagai metode analisis dalam penelitian ini. Temuan ini mengungkapkan bahwa pertimbangan pasar tenaga kerja, imbalan keuangan / gaji, dan pelatihan profesional tidak berdampak signifikan pada keputusan mahasiswa akuntansi untuk menjadi akuntan, sedangkan lingkungan kerja memiliki dampak yang signifikan. akuntansi untuk mengejar karir sebagai akuntan.

Kata kunci: Pilihan karir; pertimbangan pasar kerja; lingkungan kerja; imbalan moneter; pelatihan profesional 


\section{PENDAHULUAN}

Secara umum manusia itu memiliki Secara umum manusia itu memiliki sifat bawaan supaya dapat tercapainya sesuatu yang dicita-citakan. Pekerjaan yang sudah dimiliki Seorang individudiharapkan dapat memenuhikebutuhannya. Untuk mencapai sukses maka perlu suatu perencanaan dalam karir, Oleh karena itu stimulasi diperlukan secara matang sejak menjadi mahasiswa terkait karir dengan memanfaatkan waktu secara optimal serta fasilitas belajar dengan baik. Pemilihan karir dan jenis karir merupakan suatu faktor yang perlu untuk diteliti, adanya penelitianseperti ini maka dapat diketahui bahwa yang diminati mahasiswa dalam memilihkarir perlu membuat penyusunan program supaya dapat berjalan secara efektif bagi mahasiswa.

Mahasiswa memilih pekerjaan akuntansi diharapkan dapat merencanakan pendidikan akuntansi dan kurikulum yang sesuai dengan tuntutan dunia kerja sehingga apabila mahasiswa telah menyelesaikan studi maka dapat memiliki kemampuan dibidangnya.

\section{KAJIAN LITERATUR}

Pasar kerja mempertimbangkan akses informasi terkait peluang kerja dengan memperhatikan keamanan kerja. Novia Eriska (2017) [4] melakukan penelitian mengenai menjadi akuntan publik dalam karir yang dipilih dipengaruhi berbagai faktor. Hasilnya menunjukan bahwa pertimbangan pasar kerja berpengaruh pada pemilihan karir oleh mahasiwa akuntansi menjadi seorang akuntan publik. Jadi hipotesis pertama diusulkan.

$\mathrm{H}_{1}$ : pertimbangan pasar kerja secara signifikan dapat berpengaruh terhadap pemilihan karir mahasiswa akuntansi sebagai akuntan.

Lingkugan kerja merupakan segala sesuatu yang ada disekitar pekerja yang dapat mempengaruhi dirinya dalam melakukan tugas-tugas yang dijalaninya. Fakor yang mempengaruhi pemilihan karir, maka hasilnya menunjukkan pengaruh lingkungan kerja dalam pemiliham karir profesi terhadap mahasiswa akuntansi. Sehingga hipotesis kedua sebagai berikut ini:

$\mathrm{H}_{2}$ : Pengaruh Lingkungan kerja terhadap pemilihan karir mahasiswa akuntansi sebagai akuntan secara signifikansi.

Rio Rahmat Yusran (2017) [5] melakukan riset mengenai analisis suatu aspek minat yang dipengaruhi oleh pemilihan karir dari penelitian tersebut memiliki berpengaruh positif. Berdasarkan hasil maka hipotesisnya :

$\mathrm{H}_{3}$ : Penghargaan finansial/gaji secara signifikan dapat berpengaruh terhadap pemilihan karir mahasiswa akuntansi.

Pelatihan Profesional Terhadap Pemilihan Karir Mahasiswa Akuntansi Sebagai Akuntan

Aspek-aspek yang mempengaruhi mahasiswa akuntansi dalam pemilihan karir menjadi akuntan publik dari Ulva Aulia, 2016 menunjukan bahwa pertimbangan pelatihan profesional mempengaruhi secara relevan pada pemilihan karir menjadi public accountant. Dari variabel tersebut dirumuskan hipotesis sebagai berikut:

$\mathrm{H}_{4}$ : Pelatihan profesional secara signifikan dapat berpengaruh terhadap pemilihan karir mahasiswa akuntansi sebagi akuntan.

\section{METODE PENELITIAN}

Sugiyono (2016) mengatakan kuantitatif dipakai untuk mengetahui populasi, sampel tertentu, sedangkan pada instrument dilakukan pengumpulan data, dan analisis data bersifat statistik.

Pengumpulan data melalui angket yang terpakai 72 mahasiswa yakni mahasiswa semester $\mathrm{V}$ berjumlah 38 dan VII dengan jumlah 34 pada Program Studi Akuntansi Universitas Muhammadiyah Cirebon dengan memakai alat analisis 
deskriptif, asumsi klasik dan regresi linier berganda.

Tabel 1. Koefisien Determinan $\left(\mathbf{R}^{2}\right)$

\begin{tabular}{|c|c|c|c|c|}
\hline Model & $\mathrm{R}$ & $\begin{array}{c}\mathrm{R} \\
\text { Squer }\end{array}$ & $\begin{array}{c}\text { Adj R } \\
\text { Square }\end{array}$ & $\begin{array}{c}\text { Std } \\
\text { Error of } \\
\text { The } \\
\text { Estimet }\end{array}$ \\
\hline 1 & 623 & 388 & 351 & 2.32387 \\
\hline
\end{tabular}

Sumber: Data Diolah

Tabel diatas menunjukan faktor $\left(\mathrm{R}^{2}\right)$ 0,351 atau $35,1 \%$ yang berarti pemilihan karir akuntan dapat dipaparkan pada variabel independen (pertimbangan pasar kerja, lingkungan kerja, pengharagan finansial/gaji dan pelatihan profesional). Sisanya $(100 \%-35,1 \%=64,9 \%)$ oleh fakor lain diluar model.

\section{Uji Parsial}

Tabel 2 Hasil Uji Parsial Coefficients $^{\mathrm{a}}$

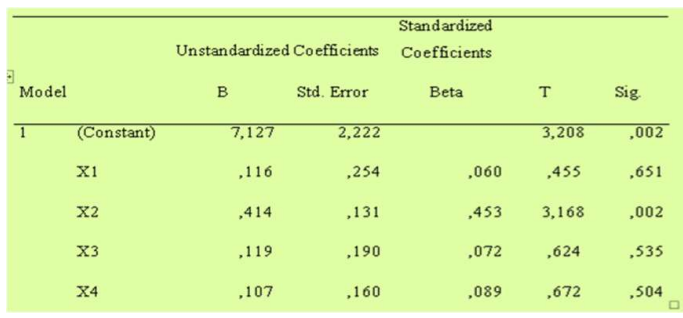

Sumber: Data Diolah

Hasil pengujian pertimbangan pasar kerja dipeoleh thitung sebesar $0,455<$ tabel 1.993 dengan sig $0,651>0,05$ maka pertimbangan pasar kerja tidak berpengaruh yang subtansial terhadap pemilihan karir, maka hipotesis ditolak. Dan pengujian lingkungan kerja diperoleh $t_{\text {hitung }}$ sebesar 3,168 $>t_{\text {tabel }} 1,993$ dengan signifikansi sebesar $0.02<0,05$ menunjukan bahwa memiliki signifikan terhadap pemilihan karir. Sedangkan penghargaanfinansial/gaji diperoleh thitung sebesar $0,624<t_{\text {tabel }} 1,993$ dengan tingkat signifikan sebesar $0,535>0,05$ menunjukan tidak terdapat pengaruh penghargaan finansial terhadap pemilihan karir.

\section{HASIL DAN PEMBAHASAN}

\section{Pertimbangan Pasar Kerja}

Mahasiswa akuntansi mempunyai presepsi pertimbangan pasar kerja tidak berpengaruh terhadap pemilihan karir sebagai akuntan (akuntan publik, akuntan pendidik, akuntan peusahaan, dan akuntan pemerintah). Hasil penelian ini tidak sesuai dengan penelitian yang dilakukan oleh Mega Sari Kudadiri dan Hek (2018) [2] yang menyatakan bahwalingkungan kerja memiliki pengaruh yant signifikan terhadap pemilihan karir sebagai akuntan. Namun di sisi lain hasil penenlitian ini sejalan dengan penelitian yang dilakukan oleh Erista (2017) dan Aulia (2016) yang menunujukan bahwa pertimbangan pasar kerja tidak memiliki pengaruh yang sinifikan terhadap pemilihan karir mahasiswa akuntansi.

Hal ini diduga karena mahsiswa akuntansi yang memilih karir akuntan (akuntan publik, akuntan pendidik, akuntan peusahaan, dan akuntan pemerintah) tidak dilihat dari aspek keamanan kerja yang mennjamin dan juga kemudahaan dalam mengakses lapangan pekerjaan.

\section{Lingkungan Kerja}

Hasil pengujian menunjukanbukti bahwa lingkungan kerja berpengaruh terhadap pemilihankarir akuntan. Hasil ini didukung oleh penelitian yang dilakukan oleh Mutmainah Daulay (2016), Mega Sari Kudadiri dan Hek (2018) serta penelitian yang dilakukan oleh Novia Erista (2017) yang menunjukan bahwa lingkungan kerja memilki pengaruh yang sinifikan terhadap pemilihan karir mahasiswa akuntansi.

Hal ini diduga karena mahasiswa yang memilih karir akuntan (akuntan publik, akuntan pendidik, akuntan peusahaan, dan akuntan pemerintah) dengan harapan lingkungan kerja yang menyenangkan supaya dapat menciptakan kenyamanan dalam bekerja. 


\section{Penghargaan Finansial/Gaji}

Hasil penenlitian menunjukan bahwa persepsi mahasiswa akuntansi pada penghargaan finansial tidak berpengaruh terhadap pemilihan karir akuntan. Hasil ini sesuai dengan penelitian yang dilakukan Novia E (2016), Murni,dkk (2020) serta penelitian oleh Asmoro,dkk (2016) bahwa pengharagaan finansial/gaji tidak berpengaruh terhadap pemilihan karir mahasiswa akuntansi.

\section{Pelatihan Profesional}

Hasil penenlitian inimenunjukan bahwa pelatihan profesional terhadap pemilihan karir akuntan tidak berpengaruh. Hasil penelitian ini tidak sejalan dengan Novia Erista (2017). Namun di sisi lain hasilpenelitian ini sejalan dengan penelitian yang dilakukan oleh Susanto (2019) serta Janiman dan Basuki (2020) yang menunjukan bahwa pelatihan profesional tidakberpengaruh terhadap pemilihan karir mahasiswa akuntansi.

Hal ini diduga karena pelatihan profesional akan mempengaruhi waktu kerja karyawan itu sendiri, sehingga dinilai sebagai suatu hal yang kontrapduktif, disaat karyawan membutuhkan waktu yang lebih unuk beristirahat sehabis pekerjaan rutin yang ditekuninya. Hasil pengujian pelatihan profesional diperoleh $\mathrm{t}_{\text {hitung }}<\mathrm{t}_{\text {tabel }}$ yaitu $0,672<1,993$ dengan taraf signifikan $0,504>0,05$ menunjukan tidak berpengaruh terhadap pemilihan karir, dengan demikian hipotesis tidak terima.

\section{KESIMPULAN DAN SARAN}

\section{Kesimpulan}

Faktor-faktor yang mempengaruhi pemilihan karir pada mahasiswa akuntansi untuk menjadi akuntan mencakup lingkungan kerja tetapi untuk pertimbangan pasar kerja, penghargaan finansial/gaji, dan pelatihan profesional tidak memilikipengaruh.

\section{Saran}

a. Diharapkan peneliti selanjutnya dapat menambahkan elemen-elemen yang mempengaruhi pemilihan karir profesi akuntan tidak hanya dari pertimbangan pasar kerja, lingkungan kerja, penghargaan finansial/gaji, dan pelatihan profesional namun juga ada faktor-faktor lain seperti nilai-nilai sosial, pengakuan profesional, personalitas dan lain-lain.

b. Harapan peneliti selanjutnya dapat memperluas objek penelitian seperti menggunakan responden dari berbagai universitas yang ada di Cirebon bahkan Jawa Barat

c. Untuk akademisi, mutu keilmuan mahasiswa sehingga siap pakai untuk bekerja dan diharapkan keseragaman kurikulum sehingga tujuan yang dimiliki lebih baikdalam menentukan profesi.

\section{UCAPAN TERIMAKASIH}

Terimakasih kepada rekan-rekan di Fakultas Ekonomi terutama prodi Akuntansi UM Cirebon yang sudah banyak memotivasi dan membantu terkait pengembangan riset ini.

\section{DAFTAR PUSTAKA}

[1] Fridolin Prakoso. (2018). "FakorFaktor Yang Mempengaruhi Pemilihan Karier Mahasiswa Akuntansi Sebagai Akuntan Atau Non Akuntan". Jurnal Universitas Sanata Dharma, Yogyakarta [2] Mega Sari Kudadiri, Tam Kim Hek. (2018)“Faktor-Faktor Yang Mempengaruhi Keputusan Mahasiswa S1 Akuntansi Dalam Pemilihan Karir Sebagai Akuntan”. Junal BINA AKUNTANSI IBBI

[3] Mutmainah Daulay. (2016)."Faktorfaktor yang Mempengaruhi Pemilihan Karir Mahasiswa Akuntansi sebagai Akuntan Publik". Junral Universitas Negeri Sumatera Utara, Medan.

[4] Novia Erista. (2017) "Analisis FaktorFaktor yang Mempengaruhi Pemilihan Karir Sebagai Akuntan Pada Mahasiswa 
Akuntansi”. Jurnal Univrsitas Maritim Raja Ali Haji, Tanjung Pinang Pusat Pembinaan Profesi Keuangan.

[5] Rio Rahmat Yusran. (2017). “Analisis Faktor-Faktor yang MempengaruhiMinat Mahasiswa Terhadap Pemilihan Karir Akuntan/Non Akuntan”. Jurnal Universitas Putera Batam, Batam

[6] Sugiyono. (2016). Metode penelitian kuantitatif, kualitatif dan $R \& D$. Bandung: PT. Alfabet

[7] Ulva Aulia. (2016) "Faktor-Faktor yang Mempengaruhi Mahasiswa Akuntansi di kota Surabaya Dalam Pemilihan Karir Sebagai Akuntan Pubik". Jurnal Universitas Airlangga, Surabaya. 